\title{
Dumbbell in ailing left ventricle lifted by warfarin
}

\author{
Ahamed Shaheer Ahmed (1) , ${ }^{1}$ Shivank Gupta, ${ }^{1}$ Hermohender Singh Isser, ${ }^{2}$ \\ Sampath Kumar ${ }^{3}$
}

${ }^{1}$ Cardiology, Vardhman Mahavir Medical College and Safdarjung Hospital, New Delhi, India ${ }^{2}$ Cardiology, VMMC and Safdarjung Hospital, New Delhi, India

${ }^{3}$ Cardiology, All India Institute of Medical Sciences, New Delhi, India

\section{Correspondence to}

Dr Sampath Kumar;

sampath.madapathi@gmail.com

Accepted 15 March 2021
Check for updates

(C) BMJ Publishing Group Limited 2021. No commercial re-use. See rights and permissions. Published by BMJ.

To cite: Ahmed AS, Gupta $S$, Isser HS, et al. BMJ Case Rep 2021;14:e241577. doi:10.1136/bcr-2021241577

\section{DESCRIPTION}

A 65-year-old man with a history of diabetes mellitus for the past 10 years presented with problems of dyspnoea on exertion New York Heart Association class II for 4 years, which worsened to class III-IV since last 1 week. He did not have any history of previous acute coronary syndrome or angina on exertion. ECG showed broad QRS complexes with interventricular conduction defect. Echocardiography showed severe left ventricular dysfunction with akinesia of inferior wall. There was a large mobile, protruding, dumbbell shaped thrombus in the left ventricle, which was attached to the inferior wall extending on both sides of the chordae of postero-medial papillary muscle (figure 1A,B; video 1). Coronary angiogram showed total occlusion of right coronary and mild disease in the left anterior descending artery. Patient was managed with enoxaparin and guideline directed medical therapy for heart failure. Repeat echocardiography done after 1 week prior to discharge showed near complete resolution of the thrombus (figure 1C). Patient did not develop any thromboembolic manifestations. Patient was discharged on warfarin, with a plan to continue the same for 6 months.

Left ventricular clot in ischaemic cardiomyopathy is frequently seen at the apex and the

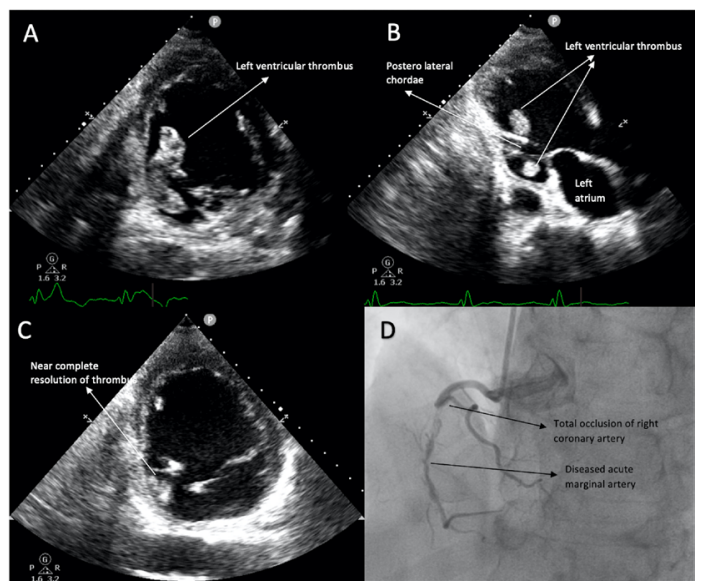

Figure 1 (A) Transthoracic echocardiography in parasternal short axis view showing thrombus in the left ventricle. (B) Transthoracic echocardiography in parasternal long axis view showing thrombus in either side of the posterior chordae. (C) Repeat echocardiography showing near complete resolution of the thrombus. (D) Right coronary artery angiogram showing complete occlusion and diffusely disease acute marginal branch.

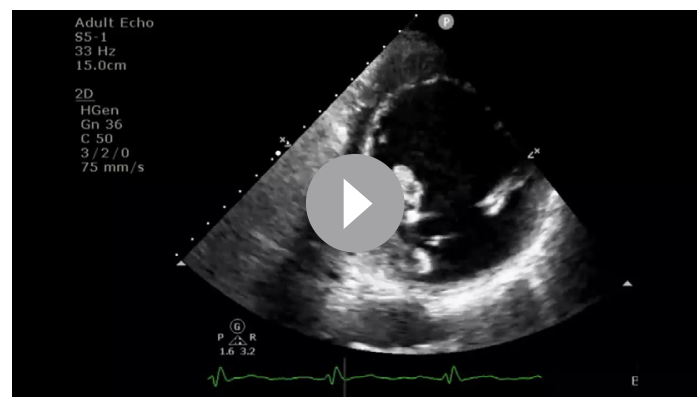

Video 1 Echocardiography in parasternal short axis view showing left ventricular clot

anterior wall. Clot in the septal wall is seen in $11 \%$ and its occurrence in the inferior wall is very rare comprising of only $3 \%$ cases with ischaemic cardiomyopathy having ventricular thrombus. ${ }^{1}$ The incidence of left ventricular clot postmyocardial infraction in the current reperfusion era is around $5 \% .^{2}$ The risk factors for development of left ventricular clot include anterior wall myocardial infarction, especially involving proximal left anterior coronary artery, severe left ventricular dysfunction (ejection fraction <30\%). ${ }^{3}$ Presence of significant mitral regurgitation might be protective against clot formation, as the enhanced early diastolic flow into the left ventricle prevents stasis. ${ }^{4}$ Mobile and protruding clots have a greater tendency for embolisation. Larger clots, thrombus with echolucency and thrombus located close to hypercontractile myocardium also have higher chances of embolisation. ${ }^{4}$ Majority of the clots embolise within the first 4 months. ${ }^{5}$ The management of left ventricular thrombus is still controversial. Anticoagulation remains the mainstay of therapy, either heparin or warfarin. Thrombolysis and surgical removal of clot were done previously, but not practised anymore. Novel Oral Anticoagulants (NOACs) are not extensively studied in this patient population. Of late there are reports of such patients being successfully treated with

Learning points

Left ventricular clot is commonly seen in the apex or the anterior wall.

- Thrombus located in the inferior wall of left ventricle is very rare.

- Mobile and protruding clots possess high risk of embolisation.

- Warfarin for 3-6 months is the mainstay of therapy for left ventricular clots. 
NOACs. ${ }^{6}$ Although there are not much data on the optimal duration of therapy, it is a routine practise to give anticoagulants for 3-6 months as the embolic risk is higher in the initial few months.

Contributors ASA was involved in conceptualisation, patient care, data collection and in writing the manuscript. SG was involved in patient care and proofreading the manuscript. HSI provided critical inputs to the manuscript. SK was involved in writing the manuscript.

Funding The authors have not declared a specific grant for this research from any funding agency in the public, commercial or not-for-profit sectors.

Competing interests None declared.

Patient consent for publication Obtained.

Provenance and peer review Not commissioned; externally peer reviewed.

ORCID iD

Ahamed Shaheer Ahmed http://orcid.org/0000-0002-2512-4689

\section{REFERENCES}

1 Jugdutt BI, Sivaram CA. Prospective two-dimensional echocardiographic evaluation of left ventricular thrombus and embolism after acute myocardial infarction. J Am Coll Cardiol 1989;13:554-64

2 Gianstefani S, Douiri A, Delithanasis I, et al. Incidence and predictors of early left ventricular thrombus after ST-elevation myocardial infarction in the contemporary era of primary percutaneous coronary intervention. Am J Cardiol 2014;113:1111-6.

3 Chiarella F, Santoro E, Domenicucci S, et al. Predischarge two-dimensional echocardiographic evaluation of left ventricular thrombosis after acute myocardial infarction in the GISSI-3 study. Am J Cardiol 1998;81:822-7.

4 Delewi R, Zijlstra F, Piek JJ. Left ventricular thrombus formation after acute myocardial infarction. Heart 2012;98:1743-9.

5 Meltzer RS, Visser CA, Fuster V. Intracardiac thrombi and systemic embolization. Ann Intern Med 1986;104:689-98.

6 Makrides CA. Resolution of left ventricular postinfarction thrombi in patients undergoing percutaneous coronary intervention using rivaroxaban in addition to dual antiplatelet therapy. BMJ Case Rep 2016;2016. doi:10.1136/bcr-2016-217843. [Epub ahead of print: 26 Oct 2016].

Copyright 2021 BMJ Publishing Group. All rights reserved. For permission to reuse any of this content visit

https://www.bmj.com/company/products-services/rights-and-licensing/permissions/

BMJ Case Report Fellows may re-use this article for personal use and teaching without any further permission.

Become a Fellow of BMJ Case Reports today and you can:

- Submit as many cases as you like

- Enjoy fast sympathetic peer review and rapid publication of accepted articles

- Access all the published articles

Re-use any of the published material for personal use and teaching without further permission

Customer Service

If you have any further queries about your subscription, please contact our customer services team on +44 (0) 2071111105 or via email at support@bmj.com.

Visit casereports.bmj.com for more articles like this and to become a Fellow 